\title{
Contribution of School Well-being and Emotional Intelligence to Student Engagement in Learning
}

\author{
Roza Eva Susanti ${ }^{*}$, Firman ${ }^{2}$, Daharnis ${ }^{3}$ \\ ${ }^{1}$ Universitas Negeri Padang \\ ${ }^{*}$ Corresponding author, e-mail: rozaeva.susanti@yahoo.com
}

\begin{abstract}
This study aims to analyze school well-being, emotional intelligence and student engagement in learning. The research was conducted using descriptive quantitative methods. The study population was 768 students of SMP Negeri 1 Padang and the research sample consisted of 201 students who were taken using random sampling technique. The instruments that used were arranged based on the constructs of the three variables, namely school well-being, emotional intelligence and student engagement in learning that had met the validity and reliability requirements. The research data were analyzed using simple regression and multiple regression. The findings of the study show that: (1) in average, student engagement in learning is in the high category, (2) school well-being and emotional intelligence are also in the high category, (3) the contribution of school well-being to student engagement in learning by $48.2 \%$, (4) the contribution of emotional intelligence to student engagement in learning by $57 \%$, and (5) the contribution of school well-being and emotional intelligence together to student engagement in learning by $62.1 \%$. The implications of the research results can be used as a basis in the preparation of guidance and counseling service programs.
\end{abstract}

Keywords: School well-being, Emotional Intelligence, Student Engagement

How to Cite: Susanti, R. E., Firman, F., Daharnis, D. (2021). Contribution of School Well-being and Emotional Intelligence to Student Engagement in Learning. International Journal of Applied Counseling and Social Sciences, 2 (1): pp. 48-54, DOI: https://doi.org/10.24036/005397ijaccs

This is an open access article distributed under the Creative Commons 4.0 Attribution License, which permits unrestricted use, distribution, and reproduction in any medium, provided the original work is properly cited. @2021 by Author

\section{Introduction}

Student engagement in learning at school is a series of activities that should be carried out actively by every student if they want to understand what they are learning and get good achievements in school. This is in line with the goals of education which is an active learning process that aims to develop all the potential of students. Frederick, Blumenfeld \& Paris (2004) stated that student behavior in learning shows the level of student engagement at school. Engagement in learning is important for a student. Reeve (2005) explains four things that make student engagement important, namely engagement as a condition for productive learning activities, engagement can predict school function, engagement in students can be controlled and shaped, engagement is also a feedback for the teacher.

Frederick, et al., (2004) define student engagement through three dimensions, namely behavioral engagement, emotional engagement, and cognitive engagement. Student engagement in learning is active student participation such as trying, being serious, concentrating, paying attention, and obeying the rules. 
The first dimension, namely behavioral engagement, students who have behavioral engagement will follow school rules, not skip truancy, and answer questions posed in class. The second dimension is emotional engagement, students who have emotional engagement have good relationships with fellow students and teachers. The third dimension, namely cognitive engagement, which consists of two components, namely psychological and cognitive. The psychological component includes goals and independent learning. The cognitive component emphasizes student investment in learning and learning motivation (Fredericks, et al., (2004).

From the description above, it can be concluded that student engagement at school is a psychological process that shows the attention, interest, investment, effort and engagement of students devoted to the learning process at school. Student engagement in learning can be maximally shaped if students are in a comfortable environment to participate in the learning process. Convenience in participating in the learning process can be interpreted as school well-being. Schools provide an environment that students feel can meet their needs at school. Konu \& Rimpela (2002) stated that school well-being is a student's subjective assessment of the state of his school which includes having, loving, being, and health. School well-being is a model based on the concept of well-being developed by Allardt (Konu \& Rimpela, 2002). The concept of well-being itself comes from the sociological theory popularized by Allardt (Alanen, et. Al., 2002), which is a condition that allows individuals to fulfill their basic needs.

In the school context, having refers to the fulfillment of students' needs for material and non-material conditions, for example the condition of the building and the school environment. In addition, there are also schedules and assignments for subjects, services (for example, administration and counseling) or forms of punishment (punishment) given to students. Loving refers to the need to develop relationships with other people to form social identities in a school climate, for example how students relate to teachers, and student relationships with students. Then, being is a need for creativity, appreciation, support and encouragement given to students. Finally, health is a physical symptom that includes the flu, the common cold to chronic illness. School well-being is a concept derived from the sociological domain so that the health aspect is included in it. However, in this study the health aspect was not analyzed because the health aspect was not directly related to psychological subjectivity and the school could not directly handle the needs of this health aspect.

Based on the description above, it can be concluded that school well-being is a school condition and learning environment that allows students to feel comfortable because of the fulfillment of the needs of having, loving, and being. This convenience supports student engagement in the learning process well.

Student engagement and academic success in school are related to a number of individual characteristics that students bring to learning situations and the characteristics of the school where the learning process occurs. Illeris (2003) also emphasized that in achieving the optimal learning process the ability factor in the cognitive and emotional dimensions of individuals in interacting with the learning environment at school is very important.

Huebner and McCullough (2000) explain that an unpleasant school experience can be a significant source of stress and reduce the quality of life of students. Huebner and McCullough's statement is supported by research by Fatimah (2010), which explains that the higher the stress experienced by students, the worse the student's assessment of their school. When students experience boredom, they will feel they do not have good social relationships and their fulfillment feels neglected. This opinion is in accordance with Torsheim's research (Fatimah, 2010) which explains that the stress experienced by students will have a negative impact on interpersonal relationships so that students feel that the learning climate at school is unpleasant. School conditions that are uncomfortable, stressful, and boring will result in students experiencing stress, isolation and depression. This situation encourages students to bring up negative behavior such as fussing in class, refusing to participate in learning, disturbing friends, not doing assignments and even skipping classes. Students who behave negatively may be because they haven't understood the lesson (not because they are not smart). Seeing this condition, the teacher should understand that in addition to intellectual intelligence, emotional intelligence also supports student engagement in the learning process. 
Goleman (2002) explains that emotional intelligence is a person's ability to regulate his emotional life by maintaining emotional harmony and expression through self-awareness skills, self-control, selfmotivation, empathy and social skills. This ability directs individual thought patterns and behavior.

In the school context, the ability to direct these patterns of thought and behavior can be the ability of students to motivate themselves to follow and be actively involved in academic activities. In addition, this ability also helps students manage stress and face various forms of challenges in completing assignments. In the context of learning, well-managed emotions can be utilized for student engagement in the learning process because when those emotions arise, students have more energy needed to engage in the learning process, complete assignments or create new things.

Based on the description above, it can show that emotional intelligence in the context of this study is the ability of students to motivate themselves to engage and direct appropriate behavior during the learning process. Emotional intelligence is also the ability to overcome frustration, control impulses, help mood when having difficulty understanding lessons, as well as the ability to empathize and cooperate on group assignments.

Emotional intelligence is also the ability to cope with frustration, control impulses, regulate the mood (mood) when having difficulty understanding lessons, as well as the ability to empathize and cooperate on group tasks.

Based on the phenomena found in schools and based on previous research, researchers want to know about student engagement learning, especially in relation to school well-being and emotional intelligence.

\section{Method}

This research uses descriptive quantitative method, with the research population of 768 students of SMP Negeri 1 Padang and the research sample of 201 students who were selected using random sampling technique. The instrument used is a scale with a Likert model about school well-being, emotional intelligence, and student engagement in learning. The three instruments were arranged based on the theoretical construct of the three research variables and had met the validity and reliability requirements. The number of valid items was 124 out of 149 items that were tested. While, the average reliability value of the three variables is 0.90 . The research data were analyzed using descriptive statistics using simple regression and multiple regression.

\section{Results and Discussion}

The research data consisted of school well-being (X1), emotional intelligence (X2), and student engagement in learning $(\mathrm{Y})$. The following shows a description of the research data.

Table 1. Description of Average (mean) and Percentage (\%) of School well-being (X1) based on Sub Variables

\begin{tabular}{ccccccccc}
\hline Aspect & Ideal & Max & Min & $\sum$ & Mean & $\%$ & DS & Cat \\
\hline Having (14) & 70 & 67 & 41 & 10899 & 54.22 & 77.46 & 4.9 & $\mathrm{H}$ \\
Loving (21) & 105 & 98 & 61 & 16378 & 81.48 & 77.6 & 7.74 & $\mathrm{H}$ \\
Being (12) & 60 & 59 & 35 & 9686 & 48.19 & 80.32 & 5.06 & $\mathrm{H}$ \\
Whole & 235 & 215 & 145 & 36963 & 183.89 & 75.88 & 17.7 & $\mathrm{H}$ \\
\hline
\end{tabular}

\begin{tabular}{lllll}
\multicolumn{2}{l}{ Information: } & & \\
Max & $:$ & Maximal score & Mean & $:$ Mean \\
Min & $:$ & Minimal score & $\%$ & $:$ Percentage \\
$\sum$ & $:$ & Total score & H & $:$ High \\
DS & $:$ & Deviation Standard & &
\end{tabular}


Table 1 shows the school well-being of students on average in the high category, with an achievement level of $75.88 \%$. This means that on average students have high school well-being. Students have a subjective assessment that the school can meet the need for a safe environment, well-available materials, avoid noise, adequate ventilation, appropriate air temperature, and so on (having). Apart from that related to the relationship between individuals in the social environment (loving), students feel they have a good relationship with the school environment, such as teachers paying attention to students, communicating well so that students feel comfortable in school. Then from the aspect of selffulfillment, students subjectively feel that the school provides opportunities for students to get selffulfillment. Students interpret that their presence in school is considered important. Based on the achievement of each indicator, it is known that all aspects of school well-being are in the high category.

Table 2. Description of Average (mean) and Percentage (\%)

Emotional Intelligence $(\mathrm{X} 2)$ based on Sub Variables

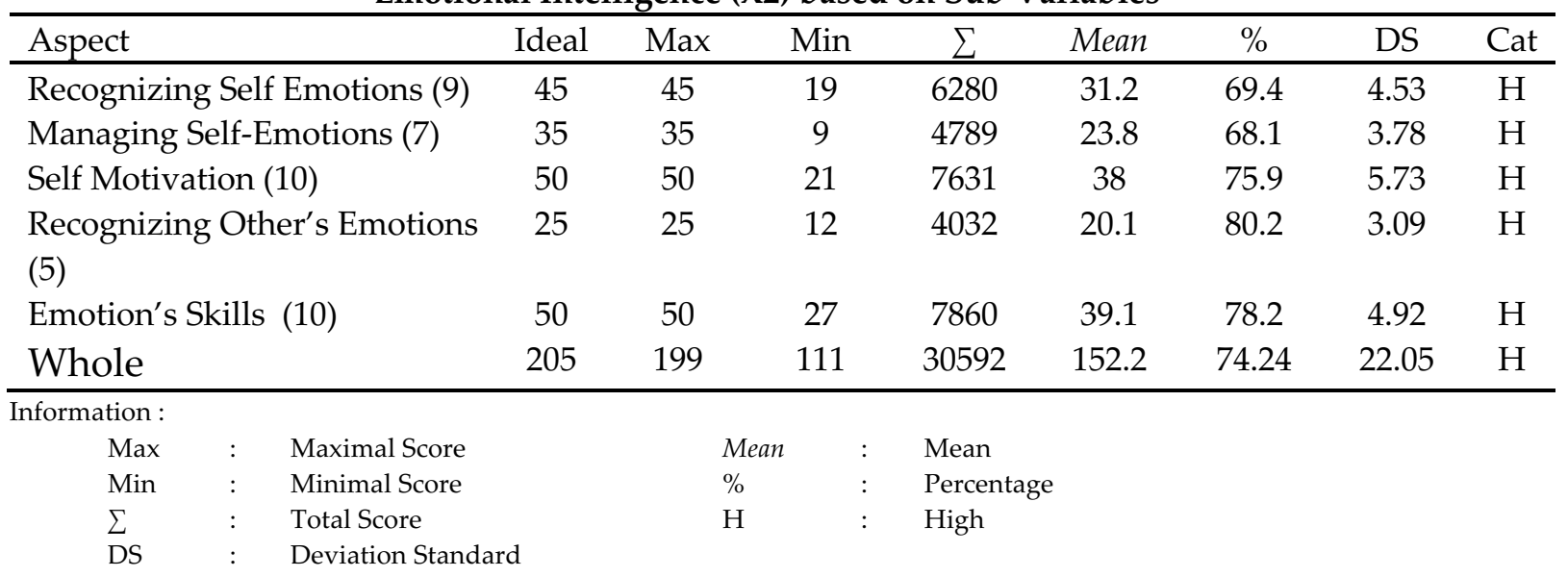

Table 2 shows that the emotional intelligence of students on average is in the high category, with an achievement level of $74.24 \%$. This means that on average students are classified as being able to regulate their emotional life by maintaining harmony with their emotions and expressions through selfawareness skills, self-control, self-motivation, empathy, and emotional skills related to the emotions of others. Emotionally intelligent students can recognize their own emotions, influence their own thoughts and behavior, know their own strengths and weaknesses, and have self-confidence (Mafthukah, 2018)

Table 3. Description of Average (mean) and Percentage (\%)

Student Engagement in Learning $(\mathrm{Y})$ based on Sub Variables

\begin{tabular}{|c|c|c|c|c|c|c|c|c|c|}
\hline \multicolumn{2}{|l|}{ Aspect } & Ideal & Max & Min & $\sum$ & Mean & $\%$ & DS & Cat \\
\hline \multicolumn{2}{|c|}{ Cognitive Engagement (15) } & 75 & 75 & 30 & 11281 & 56.1 & 74.8 & 7.88 & $\mathrm{H}$ \\
\hline \multicolumn{2}{|c|}{ Emotional Engagement (10) } & 50 & 50 & 16 & 7483 & 37.2 & 74.5 & 5.6 & $\mathrm{H}$ \\
\hline \multicolumn{2}{|c|}{ Behavioral Engagement (11) } & 55 & 55 & 31 & 9113 & 45.3 & 82.4 & 5.12 & $\mathrm{H}$ \\
\hline \multicolumn{2}{|c|}{ Whole } & 180 & 177 & 78 & 27877 & 138.6 & 77.05 & 18.6 & $\mathrm{H}$ \\
\hline \multicolumn{10}{|l|}{ Information: } \\
\hline Max & \multirow{2}{*}{\multicolumn{2}{|c|}{$\begin{array}{l}\text { Maximal Score } \\
\text { Minimal Score }\end{array}$}} & & \multicolumn{2}{|c|}{ Mean } & \multicolumn{2}{|c|}{ Mean } & & \\
\hline Min & & & & \multicolumn{2}{|c|}{$\%$} & \multicolumn{2}{|c|}{ Percentage } & & \\
\hline$\Sigma$ & \multicolumn{2}{|c|}{ Total Score } & & \multirow{2}{*}{\multicolumn{2}{|c|}{$H$}} & \multirow{2}{*}{\multicolumn{2}{|c|}{ High }} & & \\
\hline DS & Deviatio & & & & & & & & \\
\hline
\end{tabular}

Table 3 shows that the average student engagement in learning is in the high category, with an achievement level of $77.05 \%$. This means that on average students have high engagement in learning and it can be seen from the willingness of students to be involved in the learning process which appears in the form of mobilizing attention, interest and effort in learning. 
Table 4. Analysis of the Contribution of School well-being (X1), Emotional Intelligence (X2), to Student Engagement in Learning (Y)

\begin{tabular}{ccccc}
\hline No & Model & $\boldsymbol{R}$ & $\boldsymbol{R}$ Squeare & Sign \\
\hline $\mathbf{1}$ & $\mathbf{X}_{1-Y}$ & .694 & .482 & 0.000 \\
$\mathbf{2}$ & $\mathbf{X}_{2}-\mathbf{Y}$ & .755 & .570 & 0.000 \\
$\mathbf{3}$ & $\mathbf{X}_{12}-\mathbf{Y}$ & .788 & .612 & 0.000 \\
\hline
\end{tabular}

Table 4 above shows that the correlation value (R) of school well-being (X1) with student engagement learning is 0.694 , an R Square value of 0.482 , and a Sign value of 0.000 , indicating that school well-being significantly contributes to student engagement in learning with an effective contribution of $48.2 \%$. The remaining $51.8 \%$ is influenced by other variables. School well-being is a factor that contributes to student engagement in learning

The findings in this study can be understood that the higher the student's school well-being, the higher the student's engagement in learning. This shows that school well-being determines student engagement in learning (Waters \& White, 2015). The condition of the school environment including the completeness of the facilities will make student engagement in learning more active (Adriany \& Setyawan 2016). This is also explained by Dariyo (2017) that loving is very important for students because it can foster a sense of care about the learning process so that students can be actively engaged in learning.

These findings also support the research results of Kusuma, Pebriani \& Yudiana (2019), which states that student engagement in learning will increase along with the better relationship between students and teachers. Furthermore, student self-fulfillment such as gaining respect and opportunities for expression can increase student participation in learning (Rahma, Faizah, Dara \& Waffiyah, 2020).

In the second model, it can be seen that the $\mathrm{R}$ value obtained between emotional intelligence and student engagement in learning is 0.755 with an $R$ Square value of 0.570 . These results indicate that emotional intelligence has a significant contribution to student engagement learning with an effective contribution of $57 \%$. The remaining $43 \%$ is influenced by other variables. The ability of students to manage emotions will have an impact on the learning process that takes place (Pitriani, 2019).

The findings of this study are supported by the results of research by Hapsyah, Permana \& Zanthy (2019) which reveal that the emotional intelligence of students greatly influences students' problemsolving abilities in learning. Furthermore, Anisah \& Suntara (2020) revealed that students' emotional intelligence can be seen from the way students control themselves when participating in learning with the debate method, students who can control themselves will be able to provide logical statements when debating.

Furthermore, one of the characteristics of students who have good emotional intelligence is being able to control themselves from aggressive behavior and having the ability to form discussion groups in learning (Swadnyana \& Tobing, 2019). Meanwhile, students who have high emotional intelligence will show excellent self-motivating abilities so they rarely experience burnout in learning activities (Purnama, 2016).

The third model in Table 4 shows the correlation value (R) of school well-being and emotional intelligence with student engagement in learning of 0.788 . The $R$ Square value of 0.612 explains that school well-being and emotional intelligence have a joint contribution to student engagement in learning, with an effective contribution of $61.2 \%$. The remaining $38.8 \%$ is influenced by other variables not included in this study.

This shows that student participation in learning will increase along with the recognition from teachers of their abilities (Lohre, Lydersen \& Vatten, 2010). Furthermore, the results of this study are supported by the results of research by Khatimah (2015) which revealed that adequate school infrastructure will make accelerated class students more enthusiastic about learning. 
Emotional intelligence is not only about controlling emotions, but also about how to have social relationships with other people. The result of student engagement in learning is learning achievement and one of the factors that determines learning outcomes is emotional intelligence (Kinasih, 2018). Furthermore, students who have an average learning achievement have high emotional intelligence compared to other students (Hakim, Sulistiawati \& Arifin, 2018).

\section{Conclusion}

Based on the research findings, it can be concluded that school well-being and emotional intelligence contribute significantly to student engagement in learning. School well-being contributed significantly to $48.2 \%$ of student engagement in learning, emotional intelligence contributed significantly to student engagement in learning by 57\%. Simultaneously, school well-being and emotional intelligence contributed significantly to student engagement in learning with an effective contribution of $62.1 \%$.

The findings of this study indicate that student engagement learning at SMP Negeri 1 Padang is mostly influenced by emotional intelligence and school well-being. However, there are also other factors that influence such as teacher competence, limitations in the face-to-face learning process due to the COVID-19 pandemic situation, and so on. The results of this study are expected to be useful for both the school and parents to improve school well-being and emotional intelligence, so that students have an effective engagement in the learning process so that learning objectives are achieved

\section{References}

Ahmad, J. N. (2010). Penggunaan School Well Being pada Sekolah Menengah Atas (SMA) Bertaraf Internasional Sebagai Barometer Evaluasi Sekolah. Jurnal UI Untuk Bangsa Seri Sosial dan Humaniora, 102-103.

Alfansyur, A., \& Mariyani, M. (2019). Pemanfaatan Media Berbasis ICT 'Kahoot'Dalam Pembelajaran PPKN Untuk Meningkatkan Motivasi Belajar Siswa. Bhineka Tunggal Ika, 6(2): 208-216.

Andriany, N. F., \& Setyawan, I. (2017). Adversity Intelligence Dan Kesejahteraan Sekolah Pada Siswa Kelas XI Dan XII. Empati, 5(1), 24-27.

Anisah, A. S., \& Suntara, H. (2020). Penerapan Metode Pembelajaran Debate Untuk Meningkatkan Kecerdasan Emosional Siswa. Jurnal Pendidikan UNIGA, 14(1): 254-267.

Dariyo, A. (2017). Peran School Well Being dan Keterlibatan Akademik dengan Prestasi Belajar pada Siswa Sekolah Dasar. Jurnal Psikogenesis, 5(1).

Fredricks, J. A., \& McColskey, W. (2012). The measurement of student engagement: A comparative analysis of various methods and student self-report instruments. In Handbook of research on student engagement (pp. 763-782). Springer, Boston, MA.

Goleman, D. (2005). Emotional Intelligence (terjemahan).Jakarta : PT Gramedia Pustaka Utama

Hakim, A. R., Sulistiawati, S., \& Arifin, S. (2018). Hubungan Antara Kecerdasan Emosional Dan Motivasi Belajar Dengan Prestasi Belajar Matematika Siswa SMP. Teorema: Teori dan Riset Matematika,

Hapsyah, R., Permana, N., \& Zanthy, L. S. (2019). Pengaruh Kecerdasan Emosional Siswa Smp Terhadap Kemampuan Pemahaman Matematik Dan Pemecahan Masalah. Journal On Education, 1(3): 119127.

Hidayat, E. (2017). Hubungan Pembelajaran Elaborasi dan Kecerdasan Emosional Siswa dengan Hasil Belajar PAI. Tarbawi: Jurnal Keilmuan Manajemen Pendidikan, 2(01): 109-120.

Hongwidjojo, M. P., Monika, M. \& Wijaya, E. (2018). Relation of Student-Teacher Trust with School Well-Being to High School Students. Journal PSIKODIMENSIA, 17(2): 162-167.

Jati, G. W., \& Yoenanto, N. H. (2013). Kecerdasan Emosional Siswa Sekolah Menengah Pertama Ditinjau dari Faktor Demografi. Jurnal Psikologi Pendidikan dan Perkembangan, 2(2): 109-123.

Khatimah, H. (2015. Gambaran School Well-Being pada Peserta Didik Program Kelas Akselerasi di SMA Negeri 8 Yogyakarta. PSIKOPEDAGOGIA, 4(1): 20-30. 
Khoirunnisa, L. (2017). Hubungan Antara Kebiasaan Membaca Asmaul Husna dengan Kecerdasan Emosional Siswa Kelas XI MA Nurul Ummah Yogyakarta. Jurnal Pendidikan Agama Islam, 14(1): 51-68.

Kinasih, A. (2018). Hasil belajar fisika ditinjau dari kecerdasan emosional siswa sma negeri 2 sekampung. JUSTEKI Jurnal Sains \& Teknologi, 1(1): 110-114.

Konu, A.I., Lintonen, T.P., \& Rimpela, M.K. (2002). Factor structure of the School wellbeing Model. Health Education Research, 17(1): 79-87.

Lailiyah, L. M., Burhani, M. I., \& Mahanani, P. A. R. (2017). Hubungan antara iklim sekolah dengan keterlibatan siswa dalam belajar. Happiness, Journal of Psychology and Islamic Science, 1(1): 31-38.

Laumara, I., Humaedi, H., \& Abduh, I. (2018). Pengaruh kecerdasan emosional dan motivasi belajar terhadap hasil belajar pendidikan jasmani siswa di MTsN Al-Ikhlas Kilo. Tadulako Journal Sport Sciences And Physical Education, 6(1): 15-21.

Løhre, A., Lydersen, S., \& Vatten, L. J. (2010). School wellbeing among children in grades 1-10. BMC public health, 10(1): 1-7.

Maftukhah, N. A. (2019). Analisis Kecerdasan Emosional Siswa Terhadap Kemampuan Problem Solving Matematika Siswa Sekolah Menengah Pertama. Al-Hikmah: Jurnal Kependidikan Dan Syariah, 6(2): 1-10.

Mukaromah, D., Sugiyo, S., \& Mulawarman, M. (2018). Keterlibatan Siswa dalam Pembelajaran ditinjau dari Efikasi Diri dan Self Regulated Learning. Indonesian Journal of Guidance and Counseling: Theory and Application, 7(2): 14-19.

Muniroh, A., Degeng, I. N. S., Hitipeuw, I., \& Hidayah, N. (2016). Peningkatan Academic Engagement Siswa melalui Penerapan Model Problem Based Learning di Madrasah Tsanawiyah. Jurnal Pendidikan Humaniora, 4(1): 36-52.

Nurjanah, R. (2013). Hubungan Tingkat Partisipasi dalam Kegiatan Ekstrakulikuler dengan tingkat Kecerdasan Emosional siswa SMA N 14 Jakarta. Skripsi. Universitas Indonesia Jakarta: Tidak dipublikasikan.

Pitriani, P. (2019). Pengaruh Problem Based Learning (PBL) terhadap Kecerdasan Emosional Siswa SMP. In Curup Annual Conference on Math (CACM) (Vol. 1, No. 1, pp. 1-5).

Purnama, I. M. (2016). Pengaruh kecerdasan emosional dan minat belajar terhadap prestasi belajar Matematika di SMAN Jakarta Selatan. Formatif: Jurnal Ilmiah Pendidikan MIPA, 6(3): 233-245.

Rahma, U., Faizah, F., Dara, Y. P \& Waffiyah, N. (2020). Bagaimana meningkatkan school wellbeing? memahami peran school connectedness pada siswa SMA. JIPT (Jurnal Ilmiah Psikologi Terapan), 8(1): 43-53.

Ramdani, Z \& Prakoso, B. H. (2019). Integritas Akademik: Prediktor Kesejahteraan Siswa di Sekolah. Indonesian Journal of Educational Assessment, 2(1): 29-39.

Reeve, J., \& Tseng, C. M. (2011). Agency as a fourth aspect of students' engagement during learning activities. Contemporary Educational Psychology, 36(4): 257-267.

Sa'adah, U., \& Ariati, J. (2018). Hubungan antara student engagement (keterlibatan siswa) dengan prestasi akademik mata pelajaran matematika pada siswa kelas XI SMA Negeri 9 Semarang. Empati, 7(1): 69-75.

Swadnyana, I., \& Tobing, D. H. (2019). Hubungan antara kecerdasan emosional dan agresivitas pada remaja madya di SMA Dwijendra Denpasar. Jurnal Psikologi Udayana, 6(2): 1125-1134.

Waters, L., \& White, M. (2015). Case study of a school wellbeing initiative: Using appreciative inquiry to support positive change. International Journal of Wellbeing, 5(1): 19-32.

Wernick, L. J., Kulick, A., \& Chin, M. (2017). Gender identity disparities in bathroom safety and wellbeing among high school students. Journal of youth and adolescence, 46(5): 917-930.

Wijayanti, P. A. K., Pebriani, L. V., \& Yudiana, W. (2019). Peningkatan subjective well-being in school pada siswa melalui "peer support and teaching method program". Journal of Psychological Science and Profession, 3(1): 31-42. 